\title{
SOLITARY URETERAL METASTASIS OF CARCINOMA STOMACH : AN UNUSUAL PRESENTATION
}

\author{
MD. MAHMUD-UR-RAHMAN ${ }^{1}$, AKM SHAHADAT HOSSAIN ${ }^{1}$, HAFIZ-AL-ASAD ${ }^{1}$, MD. MAHFUZUR RAHMAN ${ }^{1}$, \\ LUTFUL HASAN 1 \\ ${ }^{1}$ Department of Urology, Dhaka Medical College Hospital
}

\begin{abstract}
:
Ureteral metastasis from gastric cancer is rare. It is usually diagnosed in the setting of an advanced gastric cancer or on postmortem examination. Isolated ureteral metastasis without involvement of other sites is extremely rare. We describe a 35-years age woman with gastric cancer and right ureteral metastasis. She presented with right flank pain due to right sided hydro-ureteronephrosis following ureteral obstruction. Surgical relief of the obstruction was sought and the surgical biopsy specimens showed metastatic adenocarcinoma in the ureteral wall. A search for the primary lesion revealed gastric cancer. She denied any symptoms referable to her upper $\mathrm{GI}$ tract.
\end{abstract}

Keywords: Gastric cancer · hydronephrosis · hydroureter · ureteral metastasis

Bangladesh J. Urol. 2018; 21(1): 40-42

\section{INTRODUCTION}

Ureteral obstruction caused by gastric cancer may occur by any of the following three mechanisms: direct extension from the primary site, peritoneal deposit, or lymph node metastasis. There have been a considerable number of indistinguishable cases. ${ }^{1}$ This complication is usually seen in patients with advanced cancer $r^{1,2}$ or found at autopsy. ${ }^{3} \mathrm{~A}$ sclerotic reaction induced by cancer cells invading the periureteral region without direct invasion of the ureter, may result in ureteral obstruction. ${ }^{4-7}$ This condition is known as secondary or malignant retroperitoneal fibrosis. ${ }^{3}$ Metastasis to the ureter from the primary site through lymphatics and/or blood vessels ${ }^{8}$ ${ }^{-9}$ may also happen but are quite rare. We encountered a patient with gastric cancer who presented with hydroureteronephrosis caused by ureteral metastasis, without any symptoms referable to the primary lesion.

\section{Case Report}

A 35-year age woman, House wife from Dhaka was admitted to the department of Urology on 26/12/2016 with a 2 month history of right colic flank pain. There was no haematuria, micturition complaints. Physical examination was within normal limits except she was

Correspondences: Md. Mahmud-Ur-Rahman, Department of Urology, Dhaka Medical College Hospital mildly anaemic. An abdominal ultrasound examination revealed grade 2 Hydronephrosis and hydroureter, on CT urography suggested stricture in lower part of right ureter at pelvic inlet level causing Hydro-Ureteronephrosis On Urine R/M/E: RBC was 1-2/HPF, Serum creatinine \& urer level were $0.72 \mathrm{mg} / \mathrm{dl} \& 24 \mathrm{mg} / \mathrm{dl}$ respectively. Other laboratory findings were normal except for mild anaemia $(\mathrm{Hb}: 9.9 \mathrm{~g} / \mathrm{dl})$. During retrograde pyelography'!stricture was found at the level of Junction between upper and mid ureter. Contrast did not pass beyond that, even guide wire could not be negotiated. On ureteroscopy'!failed to negotiated beyond stricture as lumen was completely obliterated. So exploration underwent by making modified Gibson incision. Resection of stenosed part of ureter and ureteroureterostomy was done. Resected tissue was sent for histopathology, there was no colonic or any other retroperitoneal growth no enlarged lymphnode was found.

Histopathological examination revealed ureteral wall invasion by adenocarcinoma. Then we underwent searching for primary site and evaluate some cancer markers like-

\begin{tabular}{lcc}
\hline Test & Result & References \\
\hline CEA & $1.3 \mathrm{ng} / \mathrm{ml}$ & upto $5 \mathrm{ng} / \mathrm{ml}$ \\
CA 19.9 & $12.5 \mathrm{u} / \mathrm{ml}$ & upto $18.7 \mathrm{u} / \mathrm{ml}$ \\
CA 125 & $79.8 \mathrm{u} / \mathrm{ml}$ & upto $35 \mathrm{u} / \mathrm{ml}$ \\
\hline
\end{tabular}


S bilirubin, SGPT \& S. Alkaline phosphatase were within normal limit. Abdominal and Pelvic CT Scan was essentially normal except for for the hydroureteronephrosis. On Endoscopy of upper GIT : Shows one large ulceroproliferative, friable growth with contact bleeding at the proximal and mid body. Biopsy was taken from the growth and report snowed a poorly differentiated

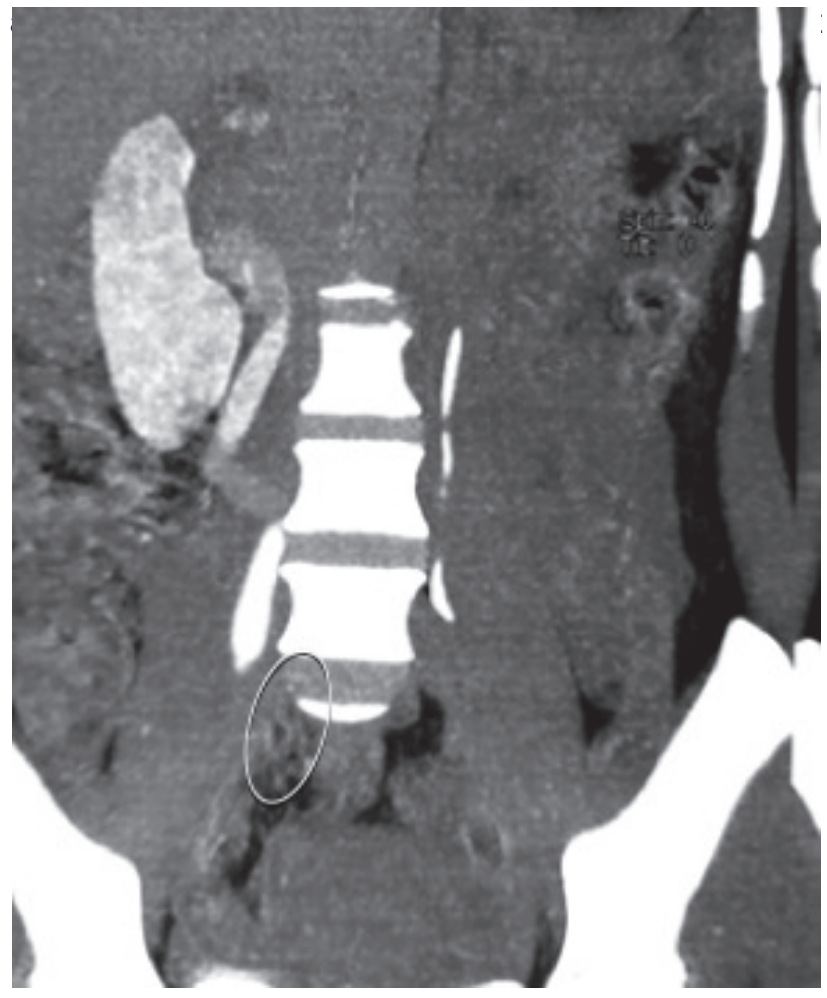

Figure 1. Showing Stricture at the level of junction between upper \& middle third of the right ureter.

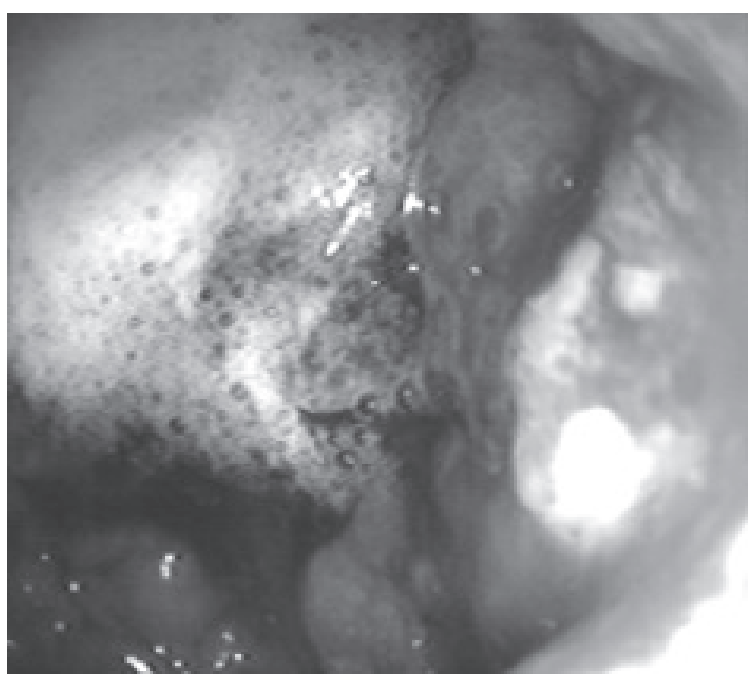

Figure 3. Multiaxial CT scan showing right sided hydroneprosis

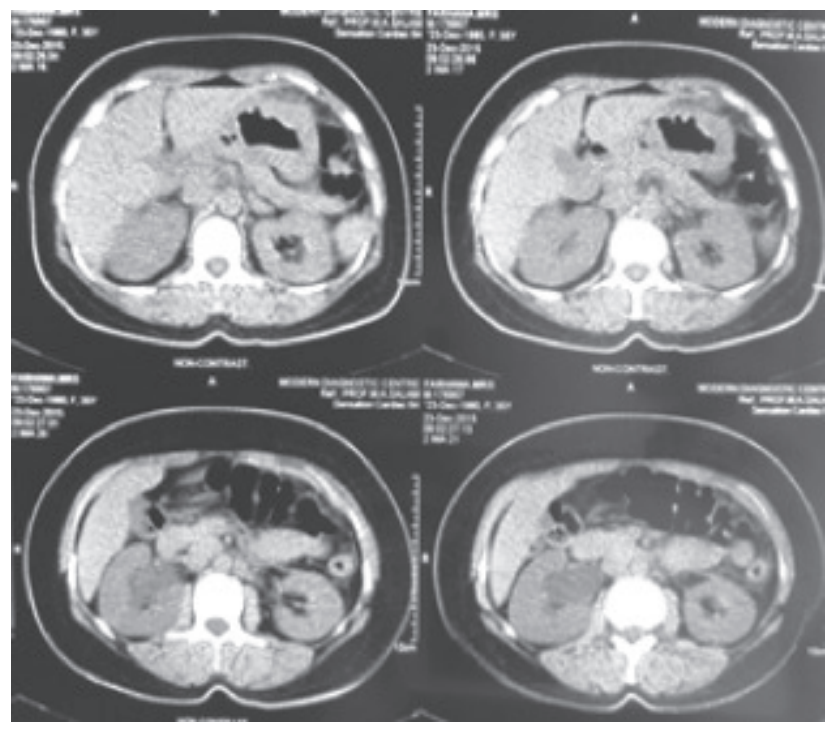

Figure 2. Endoscopic view of ulceroinfiltrative lesion

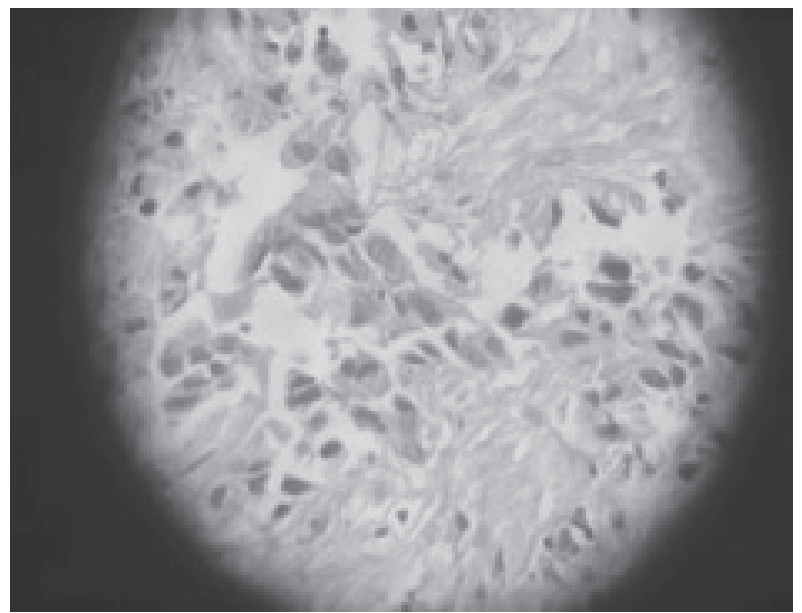

Figure 4. Histopathological view of gastric ulceroinfiltrative lesion consistent with a poorly differentiated adenocarcinoma.

of surgery for further management.

\section{Discussion}

Distant ureteral metastasis first appeared in the literature in $1909,{ }^{10}$ and Schlagintweit reported the first case of gastric cancer metastasizing to the ureter in $1911 .{ }^{11}$ Richie et al ${ }^{12}$ found 160 cases in published the literature up to 1979. Most of the tumors were diagnosed postmortem. The most common primary sites were breast, colon, prostate, and cervix. Distant metastasis from gastric carcinoma has occasionally been reported. ${ }^{12}{ }^{15}$ Differentiating between primary and secondary ureteral tumors may be rather difficult. 
MacKenzie and Ratner ${ }^{8}$ first proposed rigid criteria for true ureteral metastasis, stating that in metastatic growths of ureters, malignant cells can always be demonstrated in the perivascular lymphatic spaces or in the blood vessels around the ureter. Later, Presman and Ehrlich ${ }^{9}$ modified these criteria as follows: demonstration of malignant cells in a portion of the ureteral wall along with the absence of any neoplasm in adjacent tissues. ${ }^{15}$ This modified criteria has been widely accepted and used. A focal stenosis in right midureter without tumoral lesions around the right ureter or in the retroperitoneal space during surgery in our patient, indicates that it was a true ureteral metastasis from the stomach. There has been no report describing any effective therapy for this condition. Finding ureteral metastasis implies an advanced gastric cancer even if the primary lesion is not locally advanced.

\section{References}

1 Bartels EC. Carcinoma of the stomach with bilateral ureteral metastasis. Minn Med. 1933; 16: 578 579.

2 Liaw CC, Chuang CK, Chen JS, Chang HK. Gastric cancer with obstructive uropathy: clinical experience with 17 cases. Chang Gung Med J. 1997; 20: 286 - 292.

3 Cohen WM, Freed SZ, Hasson J. Metastatic cancer to the ureter: a review of the literature and case presentation. J Urol. 1974; 112: 188 - 189.

4 Jonsson G, Lindstedt E, Rubin SO. Two cases of metastasizing scirrhous gastric carcinoma simulating idiopathic retroperitoneal fibrosis. Scand J Urol Nephrol. 1967; 1: 299 - 302.

5 Thomas MH, Chisholm GD. Retroperitoneal fibrosis associated with malignant disease. Br J Cancer. 1973; 28: 453 - 458.
6 Usher SM, Brendler H, Ciavarra VA. Retroperitoneal fibrosis secondary to metastatic neoplasm. Urology 1977; 9: 191 - 194.

7 Dohmen K, Mizukami Y, Tanaka K, et al. Retroperitoneal fibrosis associated with scirrhous gastric cancer. Gastroenterol Jpn 1993; 28: 699 705.

8 MacKenzie DW, Ratner M. Metastatic growth in the ureter. Areport of three cases and a brief review of the literature. Can Med Assoc J. 1931; 25: 265 -270 .

9 Presman D, Ehrlich L. Metastatic tumors of the ureter. J Urol. 1948; 59: 312 - 325.

10 Stow B. Fibrolymphosarcomata of both ureters metastatic to a primary lymphosarcoma of the anterior mediastinum of thymus origin. Ann Surg. 1909; 50: $901-906$.

11 Schlagintweit F. Metastatische karzinose der ureteren mit anurie bei gleichzeitiger nephritis. $Z$ Urologie. 1911; 5: 665-671.

12 Richie JP, Withers G, Ehrlich RM. Ureteral obstruction secondary to metastatic tumors. Surg Gynecol Obstet. 1979; 148: 355 - 357.

13 Fontana D, Garbarini A, Giraudi G. A case of gastric carcimoma revealed by a ureteral metastasis. Panminerva Med. 1974; 16: 165 - 170.

14 Fitch WP, Robinson JR, Radwin HM. Metastatic carcinoma of the ureter. Arch Surg. 1976; 111: 874 -876 .

15 Shimoyama Y, Ohashi M, Hashiyuchi N, et al. Gastric cancer recognized by metastasis to the ureter. Gastric Cancer. 2000; 3: 102 - 103. 